\title{
SYTUACJA ADMINISTRACYJNOPRAWNA RODZINY PACJENTA W STANIE TERMINALNYM
}

\section{Streszczenie}

Stan terminalny pacjenta wywiera konkretny wptyw na jego rodzinę. Na ta rzeczywistość, której podlega rodzina pacjenta składa się m.in.: lęk, obawa przed samotnościa, bezradnościa, śmiercia, umieraniem, otrzymaniem potrzebnego sprzętu, awaria sprzętu, bólem i cierpieniem chorego, pogorszeniem statusu materialnego, izolacja spoteczna, widokiem i kontaktem z ciałem zmarłego, swoimi emocjami, czy reakcją na śmierć innych członków rodziny.

Opieka paliatywna to działanie, które poprawia jakość życia chorych i ich rodzin, stojacych wobec problemów zwiąanych z zagrażajaca życiu, postęujaca choroba, poprzez zapobieganie i znoszenie cierpienia dzięki wczesnej identyfikacji oraz ocena i leczenie bólu i innych problemów: somatycznych, psychologicznych, socjalnych i duchowych. Stanowi więc ona adekwatna reakcję na stan człowieka będacego $w$ fazie terminalnej oraz jego rodziny.

Sytuacja administracyjnoprawna rodziny pacjenta $w$ stanie terminalnym pozostaje $w$ funkcji sytuacji chorego terminalnie i jest z niq (z ta sytuacja) silnie sprzężona. Oznacza to, że im bardziej będzie poprawiać się sytuacja administracyjnoprawna pacjenta, tym lepsza będzie sytuacja administracyjnoprawna jego rodziny. Co oznacza lepsza? Punkt wyjścia stanowi dla nas prawo do godnego umierania, zakotwiczone w Konstytucji Rzeczypospolitej Polskiej. To właśnie w tym

* Mgr Mateusz Kruczkowski - doktorant w Katedrze Prawa Administracyjnego i Samorządu Terytorialnego, Wydział Prawa i Administracji Uniwersytetu Kardynała Stefana Wyszyńskiego w Warszawie, sekretarz Sieci naukowej: Wykluczenie społeczne. Zainteresowania naukowo-badawcze: aksjologia prawa administracyjnego, zasada pomocniczości, zasada godności ludzkiej, prawo do dobrej śmierci. 
prawie, prawie do umierania w spokoju największym z możliwych $i$ z należna mu ludzka godnościa, ukonkretnia się godność czlowieka w fazie terminalnej.

Słowa kluczowe: opieka paliatywna $i$ hospicyjna, rodzina, sytuacja administracyjnoprawna, prawo do godnej śmierci, chory terminalnie.

\section{Pacjent umierający}

Powszechnym faktem jest, że życie ludzkie tutaj na ziemi ma swój początek i koniec. Prawdy tej nikt nie kwestionuje. Śmierć jest zjawiskiem dotykającym każdego i jako takie jest też przedmiotem zainteresowania przez stanowione prawo. Kwestią stosunkowo młodą jest natomiast określenie schyłkowego etapu życia człowieka mianem stanu terminalnego. Etap ten nabrał szczególnego znaczenia m.in. w kontekście rozwoju nieuleczalnych chorób i paradoksalnie w obliczu gigantycznego postępu w zakresie medycyny. Przykładem może być tutaj np. rozwój chorób nowotworowych w Polsce w ostatnim stuleciu' ${ }^{1}$. Łacińskie terminus, rozumiane jako: koniec, schyłek, finał, granica, odsyła nas wprost do krańcowego okresu ludzkiego życia ${ }^{2}$. Okres ten możemy rozróżnić na następujące etapy: stan przedterminalny, właściwy stan terminalny oraz okres agonalny. Stan przedterminalny jest to faza choroby, wobec której zakończono leczenie przyczynowe (przedłużające życie), ale w której chory pozostaje w dobrym stanie ogólnym, co wyraża się w sprawności ruchowej i w braku dolegliwości ${ }^{3}$. Etap ten może trwać nawet kilka lat. Właściwy stan terminalny dotyczy osoby, wobec której także zakończono leczenie przyczynowe (przedłużające życie), ale chory wymaga już opieki z uwagi na nieodwracalne pogorszenie stanu ogólnego, a także z powodu narastających dolegliwości fizycznych. Trwa on kilka tygodni (od 6 do 8). Okres agonalny natomiast bezpośrednio poprzedza śmierć chorego ${ }^{4}$ - trwa zwykle

1 W Polsce, według danych GUS za rok 2014, zmarło 376467 Polaków, z czego 100318 z powodu nowotworu, por. Rocznik Demograficzny 2016, red. D. Rozkrut, Główny Urząd Statystyczny, Warszawa 2016, s. 302, 326.

2 Por. P. Aszyk, Stan terminalny, w: Encyklopedia bioetyki, red. A. Muszala, Radom 2005, s. 418.

3 Por. K. de Walden-Gałuszko, Podstawy opieki paliatywnej, Warszawa 2004, s. 12.

4 Czas ten można uschematyzować w następujące etapy: (1) życie zredukowane, polegające na obniżeniu fizjologicznych czynności podstawowych układów, (2) życie minimalne, w którym zachodzi dysregulacja ważnych czynności i dalsze obniżanie przejawów życia, (3) śmierć pozorna, będąca okresem życia minimalnego stwarzającego pozory śmierci, (4) śmierć kliniczna, w której ustaje czynność podstawowych układów; (5) życie 
2-3 doby i przejawia się stopniową narastającą niewydolnością podstawowych organów, zaburzeniami metabolicznymi oraz zaburzeniami świadomości ${ }^{5}$.

Wreszcie stan terminalny można ująć dynamicznie. W tej perspektywie jest to aktywny, postępujący proces chorobowy, który nie odpowiada już na leczenie przyczynowe, a co więcej, stosowanie takiego leczenia jest niewłaściwe. Nieuchronną perspektywą tego procesu jest śmierć pacjenta. Człowiek w stanie terminalnym znajduje się również w konkretnej sytuacji klinicznej i społecznej, którą należy także w tym miejscu przybliżyć, a która wyraża się przede wszystkim poprzez: narastające dolegliwości fizyczne, postępujące ograniczenie sprawności ruchowej, i wynikającej z niej izolacji społecznej, ograniczenie pełnionych ról społecznych ${ }^{6}$.

Człowieka w stanie terminalnym można w końcu przedstawić poprzez strukturę jego potrzeb ${ }^{7}$. Potrzeby biologiczne pacjentów chorych terminalnie wysuwają się nam tutaj na pierwszy plan. Należy zaliczyć do nich potrzebę: oddychania, wydalania, odżywiania, utrzymania stałej temperatury ciała, czystości, unikania bólu. Drugą grupą potrzeb są potrzeby psychospołeczne. Wynikają one ze szczególnej sytuacji pacjenta, który niejednokrotnie przeżywa lęk o własne życie, przed bólem i strach przed śmiercią. Ów człowiek wymaga wręcz kontaktu z drugą osobą, w szczególności z rodziną, u których może odnaleźć akceptację i ciepło. Kolejną,

pośrednie, stanowiące okres w którym można wywołać właściwe dla danej tkanki reakcje interletalne (reakcje na bodźce chemiczne), (6) śmierć osobnicza - stan uważany za decydujący o uznaniu za zmarłego, oraz (7) śmierć biologiczna, której treścią jest wygaśnięcie wszystkich życiowych czynności tkanek i komórek. Por. S. Raszeja, Refleksje na temat tanatologii - klasycznego działu medycyny sadowej, w: Annales Academiae Medicae Gedanensis, 2005, t. 35, s. 167.

5 Por. K. de Walden-Gałuszko, dz. cyt., s. 12, por. także M. Kowalczyk, Opieka paliatywna jako jedna z form opieki nad pacjentem terminalnie chorym, w: „Państwo i Społeczeństwo", rok XII, nr 2, red. F. Gołkowski, S. Kwiatkowski, Kraków 2012, s. 76-77.

6 Por. K. de Walden-Gałuszko, dz. cyt., s. 164.

7 Wartym przytoczenia w tym miejscu jest także katalog lęków i potrzeb chorego terminalnie opracowany przez F. Buczyńskiego. Do lęków pacjenta zalicza lęk: przed bólem, byciem niepotrzebnym, powrotem do szpitala, samotnością, osieroceniem rodziny, utratą roli i pozycji, utratą niezależności (w chorowaniu), sposobem umierania, śmiercią, o ciało po śmierci, przed tym co będzie po śmierci. Do marzeń i potrzeb natomiast zalicza: nadzieję wyzdrowienia, uwolnienie od przykrych dolegliwości, spokojną i godną śmierć, realizację realnych marzeń, dokończenie realnych spraw, bycie kochanym, obecność najbliższych, uszanowanie potrzeb i autonomii, bliskość i otrzymanie pomocy, życie wieczne w szczęściu, por. F. Buczyński, Lęki i potrzeby pacjenta i jego rodziny $w$ terminalnym okresie choroby, w: VII Konferencja naukowa, Stużba człowiekowi u kresu życia, Jasna Góra 30 stycznia-1 lutego 2004 r., Częstochowa 2005, s. 28. 
ważną potrzebą chorego terminalnie są potrzeby duchowe, $i$ to niezależnie od danego światopoglądu. To właśnie w tym okresie życia człowieka pojawiają się pytania o sens. Do potrzeb duchowych należy zaliczyć też poczucie wolności, która wobec ograniczeń fizycznych ulega niejako skrępowaniu

Należy więc przyjąć, że stan terminalny dotyczy człowieka, wobec którego zakończono leczenie przyczynowe, i który wymaga już stałej opieki ze względu na jego stan ogólny i narastające dolegliwości fizyczne. Opieka ta jest realizowana przede wszystkim w ramach tzw. opieki hospicyjnej, a także przez rodzinę, przez najbliższych. I trzeba podkreślić również, że stan terminalny pacjenta wywiera konkretny wpływa na jego rodzinę. Na tą rzeczywistość, której podlega rodzina pacjenta składa się m.in.: lęk, obawa przed samotnością, bezradnością, śmiercią, umieraniem, otrzymaniem potrzebnego sprzętu, awarią sprzętu, bólem i cierpieniem chorego, pogorszeniem statusu materialnego, izolacją społeczną, widokiem i kontaktem z ciałem zmarłego, swoimi emocjami, czy reakcją na śmierć innych członków rodziny. Rodzina chorego posiada również określone potrzeby, do których trzeba zaliczyć: wyleczenie chorego, spełnienie doczesnych i duchowych spraw i marzeń chorego, uwolnienie chorego od bólu i dolegliwości, spokojną śmierć chorego, stałą pomoc i terapię wyręczającą (w pielęgnacji), przygotowanie na śmierć, obecność przy śmierci ${ }^{9}$. To wszystko - ogólnie pojęta sytuacja pacjenta chorego terminalnie, a także sytuacja jego rodziny, stanowi tło zasadniczych rozważań tego opracowania - sytuacji administracyjnoprawnej rodziny chorego terminalnie.

\section{Pojęcie sytuacji administracyjnoprawnej}

Przez sytuację prawną, według J. Bocia, można rozumieć każdą sytuację społeczną określonego podmiotu, której elementy składowe zostały ukształtowane prawnie w sposób bezpośredni lub pośredni, ze względu na konkretne zdarzenie faktyczne ${ }^{10}$. Natomiast stosunek prawny, idąc za F. Longchamps'em, występuje wówczas, gdy prawo przedmiotowe ma dla dwóch podmiotów takie znaczenie, że

8 Por. H. Cebula, Okres terminalny choroby, w: Dwudziestolecie opieki paliatywnej w Zakładzie Opiekuńczo-Leczniczym w Krakowie, red. J. Iwaszczyszyn, Kraków 2015, s. 239-242.

9 Por. F. Buczyński, dz. cyt., s. 28-29, zob. także M. Górecki, Chory terminalnie i jego rodzina, „Ruch Prawniczy, Ekonomiczny i Socjologiczny”, rok 61, zeszyt 1, Poznań 1999, s. 263-278, por. także M. Rębiałkowska-Stankiewicz, Diagnoza potrzeb rodzin pacjentów w stanie wegetatywnym, „Przegląd Pedagogiczny” 2015, nr 1, s. 223-233.

10 Por. J. Boć, Prawo administracyjne, Wrocław 2007, s. 365-366. 
w pewnych warunkach sytuacja prawna jednego podmiotu jest połączona z sytuacją prawną drugiego ${ }^{11}$. Koncepcję tę rozwinął J. Filipek, który uznał, że o istnieniu stosunku prawnego można już mówić w sytuacjach poprzedzających zdarzenia, które by w całej rozciągłości konkretyzowały czyjeś uprawnienia lub obowiązki. To z kolei pozwala na stwierdzenie, że stosunek administracyjnoprawny istnieje już w sytuacjach, w których jednostka może prawnie domagać się od administracji rozstrzygnięć dotyczących jej praw i obowiązków ${ }^{12}$.

Dla pełniejszego obrazu konsekwencji norm prawa administracyjnego przyjęto jednak w niniejszej pracy perspektywę sytuacji administracyjnoprawnej, świadomie rezygnując z kategorii stosunku administracyjnoprawnego, która zakłada istnienie bezpośredniej relacji pomiędzy podmiotami. Perspektywa ta nie przesądza o „wyższości” koncepcji sytuacji prawnej nad koncepcją stosunku prawnego lub na odwrót, w ogóle ${ }^{13}$. Niemniej jednak tak zarysowany punkt wyjścia daje nam, niezależnie od zaprojektowanej przez prawo relacji między podmiotami, możliwość przeprowadzenia analizy uprawnień i/lub obowiązków adresowanych do danego podmiotu, uprawnień i/lub obowiązków wynikających zarówno z indywidualnych aktów stosowania norm prawa administracyjnego, jak i pochodzących wprost $\mathrm{z}$ norm generalnych i abstrakcyjnych, przewidzianych w przepisach prawa powszechnego. Unikamy w ten sposób problemu, w jaki sposób za pomocą konstrukcji stosunku administracyjnoprawnego analizować nakazy i zakazy określonego zachowania, które płyną wprost z aktów normatywnych, nie wymagając konkretyzacji $\mathrm{w}$ drodze procesu stosowania prawa przez podmioty administracji publicznej ${ }^{14}$. Dodatkowo mamy również możliwość uchwycenia pośredniego oddziaływania, kształtowania się sytuacji prawnej, co stanowi novum wobec stosunku administracyjnego, w wyniku, którego kwalifikowany układ praw i obowiązków powstaje zawsze bezpośrednio ${ }^{15}$.

11 Por. F. Longchamps, O pojęciu stosunku prawnego w prawie administracyjnym, „Acta Universitatis Wratislaviensis” 1964, nr 19, Prawo XII, s. 45.

12 Por. J. Filipek, Stosunek administracyjnoprawny, Kraków 1968, s. 79-84.

13 Por. S. Nitecki, Stosunek administracyjnoprawny a samorzad terytorialny, w: Instytucje współczesnego prawa administracyjnego, Ksiega jubileuszowa Prof. zw. dra hab. Józefa Filipka, Kraków 2001, s. 507-508.

14 Por. T. Bąkowski, Administracyjnoprawna sytuacja jednostki w świetle zasady pomocniczości, Warszawa 2007, s. 23-25.

15 Por. J. Boć, dz. cyt., s. 366. 


\section{Pojęcie rodziny}

Najogólniej rzecz biorąc rodzina to instytucja i zarazem grupa społeczna oparta na więziach małżeńskich, więzi pokrewieństwa, powinowactwa lub adopcji ${ }^{16}$. To właśnie poprzez więzi, które można także opisać jako: oblubieńczość, ojcostwo-macierzyństwo, synostwo, braterstwo, każda osoba wchodzi do „rodziny ludzkiej”"17.

Konstytucja Rzeczypospolitej Polskiej z dnia 2 kwietnia 1997 r..$^{18}$ nie zawiera natomiast definicji legalnej pojęcia rodziny. Niemniej jednak rodzina $\mathrm{w}$ ustawie zasadniczej zajmuje istotne miejsce. I tak rodzina znajduje się pod opieką i ochroną Rzeczypospolitej Polskiej (Art. 18). Państwo w swojej polityce społecznej i gospodarczej uwzględnia dobro rodziny. Rodziny znajdujące się w trudnej sytuacji materialnej i społecznej, zwłaszcza wielodzietne i niepełne, mają prawo do szczególnej pomocy ze strony władz publicznych (Art. 71). Dyspozycje te znajdują swoje rozszerzenie w orzecznictwie Trybunału Konstytucyjnego (dalej: TK), które zauważa, że przepisy te nakazują podejmowanie przez państwo takich działań, które umacniają więzi między osobami tworzącymi rodzinę, a zwłaszcza więzi istniejące między rodzicami i dziećmi oraz między małżonkami ${ }^{19}$. Ponadto interpretacja przepisu Art. 18 Konstytucji każe nam widzieć rodzinę przede wszystkim jako trwały związek mężczyzny i kobiety, nakierowany na macierzyństwo i odpowiedzialne rodzicielstwo ${ }^{20}$.

Natomiast analiza ustawodawstwa zwykłego przynosi nam wiele definicji pojęcia rodzina. Abstrahując od postulatów teorii prawa, by to samo pojęcie było konsekwentnie używane na gruncie różnych aktów normatywnych, warto przytoczyć $\mathrm{w}$ tym miejscu definicję rodziny, która znajduje się $\mathrm{w}$ ustawie $\mathrm{z}$ dnia 12 marca 2004 r. o pomocy społecznej ${ }^{21}$. Według art. 6 pkt 14 tej ustawy rodzinę stanowią osoby spokrewnione lub niespokrewnione pozostające $\mathrm{w}$ faktycznym związku, wspólnie zamieszkujące i gospodarujące. Potwierdzenie tego pojęcia przynosi nam także orzecznictwo Naczelnego Sądu Administracyjnego. I tak, w wyroku z 29 sierpnia 2008 r. NSA uznał, że rodzina to osoby spokrewnione

16 Por. Z. Tyszka, Socjologia rodziny w Polsce, ,Ruch prawniczy, ekonomiczny i socjologiczny", rok LII, zeszyt 3-4, Warszawa 1990, s. 234.

17 Por. Jan Paweł II, Familiaris consortio, 15, w: Acta Apostolicae Sedis 74, Watykan 1982.

18 Dz.U. z 1997 r. nr 78, poz. 483 z późn. zm.

19 Wyrok TK z dnia 18 maja 2005 r., sygn. akt K 16/04, Dz.U. nr 95, poz. 806.

20 Por. M. Zubik, Podmioty konstytucyjnych wolności, praw i obowiązków, „Przegląd Legislacyjny" 2007, nr 2(60), Warszawa 2007, s. 26-43.

21 Dz.U. z 2017 r., poz. 1769, 1985. 
lub niespokrewnione, pozostające $\mathrm{w}$ faktycznym związku, wspólnie zamieszkujące i gospodarujące. $Z$ uregulowania tego wynika zatem, że na gruncie ustawy o pomocy społecznej relacje formalne między osobami nie odgrywają żadnej roli, natomiast znaczenie mają takie elementy jak wspólne zamieszkanie i gospodarowanie $^{22}$. Można zatem stwierdzić, że rodzina na gruncie ustawy o pomocy społecznej jest zbiorowym adresatem działań organu administracji publicznej, zbliżonym konstrukcyjnie do takich podmiotów jak: spółka cywilna, konsorcjum, czy wspólnota mieszkaniowa. Dla przykładu odmienną definicję pojęcia rodziny odnajdziemy w art. 3 pkt. 16 ustawy z dnia 28 listopada 2003 r. o świadczeniach rodzinnych ${ }^{23}$, według której rodzina oznacza odpowiednio następujących członków rodziny: małżonków, rodziców dzieci, opiekuna faktycznego dziecka oraz pozostające na utrzymaniu dzieci w wieku do ukończenia 25. roku życia, a także dziecko, które ukończyło 25. rok życia legitymujące się orzeczeniem o znacznym stopniu niepełnosprawności; do członków rodziny nie zalicza się dziecka pozostającego pod opieką opiekuna prawnego, dziecka pozostającego w związku małżeńskim, a także pełnoletniego dziecka posiadającego własne dziecko. Pojęcie rodziny przyjmuje zatem różną formę (w zakresie administracyjnego prawa materialnego, ale i nie tylko) w zależności od celu jaki dany akt normatywny ma realizować ${ }^{24}$.

Mimo powyższych uwag, z uwagi na to, że punktem wyjścia naszych rozważań jest człowiek chory terminalnie, rodzinę pacjenta chcemy jednak traktować szeroko i wydaje się, że ta różnorodność pojęcia rodzina wychodzi nam w niniejszym opracowaniu naprzeciw. Dlatego nie poprzestajemy na rozumieniu rodziny sensu stricto, będącej małżeństwem wraz z zstępnymi i wstępnymi, tworzącymi wspólne gospodarstwo domowe. Chcemy na rodzinę spojrzeć szeroko i za jako taką uznać także: (1) rodzinę niepełną (np. matka z dzieckiem); (2) rodzinę jednopokoleniową (np. bezdzietne małżeństwo); (3) rodzinę nie prowadzącą wspólnego gospodarstwa domowego (np. rodzina w separacji); (4) konkubinat, czyli parę wraz z wstępnymi i zstępnymi, niebędącą $\mathrm{w}$ formalnym związku małżeńskim, prowadzącą wspólne gospodarstwo domowe ${ }^{25}$. W końcu, w domyśle, chcemy też

22 Wyrok NSA z 29 sierpnia 2008 r. I OSK 1429/07, CBOSA.

23 Dz.U. z 2017 r. poz. 1952.

24 Por. A. Skórka, Pojęcie „Rodziny” w ustawie o pomocy społecznej i w postepowaniu o uzyskanie świadczeń z zakresu pomocy społecznej. Hybryda językowa czy celowy zamyst ustawodawcy, w: Ochrona matzeństwa i rodziny w Polsce. Zagadnienia prawne, red. J. Krzynówka, J. Krzywkowska, Olsztyn 2015, s. 269-281.

25 Por. A. Ziółkowska, A. Gronkiewicz, Rodzina w prawie administracyjnym - prolegomena, w: Rodzina w prawie administracyjnym, red. A. Ziółkowska, A. Gronkiewicz, s. 14. 
mieć na względzie pozostałe osoby, będące bliskie choremu terminalnie. Nie są to osoby spokrewnione, ale właśnie określa się je mianem bliskich, a relacja w jakiej pozostają ujmowana jest jako stosunek bliskości. Nie jest to stosunek prawny, lecz stan faktyczny, mimo to ustawodawca wiąże z nim doniosłe skutki prawne. Przykładem może być tutaj uzyskanie przez osobę bliską statusu domownika, jeśli zostanie przyjęta do wspólnoty domowej ${ }^{26}$, czy definicja osoby bliskiej (pojęcie rodziny $\mathrm{w}$ tym akcie normatywnym nie występuje) na gruncie ustawy $\mathrm{z}$ dnia 6 listopada 2008 r. o prawach pacjenta i Rzeczniku Praw Pacjenta (dalej: u.p.p.) ${ }^{27}$, gdzie osoba bliska to osoba małżonka, krewnego lub powinowatego do drugiego stopnia w linii prostej, przedstawiciela ustawowego, osobę pozostającą we wspólnym pożyciu lub osobę wskazaną przez pacjenta.

\section{Opieka paliatywna w Polsce}

Według Światowej Organizacji Zdrowia (WHO, World Health Organization) opieka paliatywna ${ }^{28}$ to działanie, które poprawia jakość życia chorych i ich rodzin, stojących wobec problemów związanych z zagrażającą życiu, postępującą chorobą, poprzez zapobieganie i znoszenie cierpienia dzięki wczesnej identyfikacji oraz ocena i leczenie bólu i innych problemów: somatycznych, psychologicznych, socjalnych i duchowych ${ }^{29}$. Jest to więc aktywna i kompleksowa opieka nastawiona na zaspokajanie wszystkich podstawowych potrzeb chorego w stanie terminalnym

26 Por. E. Koniuszewska, Wptyw powiazań rodzinnych na czynności ogólnego postepowania administracyjnego, w: Rodzina w naukach prawnych, Zbiór studiów, red. M. Tkaczuk, R. Jaworska-Stankiewicz, Szczecin 2012, s. 213-214.

27 Dz.U. z 2017 r. poz. 1318, 1524.

28 Generalnie rzecz biorąc opieka paliatywna i hospicyjna posiada jeden, tożsamy desygnat. W rzeczywistości polskiej jednak zaczyna wyłaniać się różnica znaczeniowa pomiędzy tymi pojęciami. I tak opieka paliatywna wiąże się przede wszystkim z opieką medyczną, świadczoną przede wszystkim przez wykwalifikowany personel medyczny. Zatem ma ona tutaj pewien wymiar techniczny. Natomiast opiece hospicyjnej przypisuje się wymiar duchowy, społeczny, który jest związany z pewną misją niesienia pomocy choremu. WHO jednak nie dokonuje takiego rozróżnienia, dlatego na potrzeby niniejszego opracowania przyjęliśmy również tożsamość tychże pojęć.

29 „Palliative care is an approach that improves the quality of life of patients (adults and children) and their families who are facing problems associated with life-threatening illness. It prevents and relieves suffering through the early identification, correct assessment and treatment of pain and other problems, whether physical, psychosocial or spiritual.", http://www.who.int/features/factfiles/palliative-care/en/ [dostęp: 11.01.2017 r.]. 
oraz jego rodziny, zarówno podczas choroby, jak i w czasie żałoby ${ }^{30}$. Opieka paliatywna stanowi więc adekwatną reakcję na stan człowieka będącego w fazie terminalnej. Dotyczy ona nie tylko osoby w stanie terminalnym, przeżywającą problemy psychologiczne, duchowe, rodzinne, ale także rodziny, ujawniającą nierzadko cechy zaburzeń adaptacji lub zagrożenia tym stanem ${ }^{31}$.

W wyniku analiz przygotowanych dla Parlamentu Europejskiego w 2006 r. Polska zajmowała piąte miejsce w Europie pod względem rozwoju opieki paliatywnej ${ }^{32}$. Natomiast według innego badania, którego efekty zostały zamieszczone w Atlasie Opieki Paliatywnej33, Polska znalazła się w grupie państw IVb. Jest to zbiór krajów o najwyższym poziomie rozwoju opieki paliatywnej na świecie. Poziom opieki paliatywnej w grupie IVb określany jest jako etap zaawansowanej integracji w ramach podstawowych form organizacyjnych. Cechą charakterystyczną tych krajów jest to, że opieka paliatywna wchodzi w skład systemu opieki zdrowotnej34.

Dlatego należy podkreślić, że w Polsce opieka paliatywna jest zintegrowana z systemem opieki zdrowotnej, a świadczenia z jej zakresu są refundowane przez Narodowy Fundusz Zdrowia i tym samym są bezpłatne dla pacjenta. Podstawy prawne opieki paliatywnej w Polsce wyznacza przede wszystkim ustawa z dnia 27 sierpnia 2004 r. o świadczeniach opieki zdrowotnej finansowanych ze środków publicznych $^{35}$, a także rozporządzenie Ministra Zdrowia z 29 października $2013 \mathrm{r}$. w sprawie świadczeń gwarantowanych z zakresu opieki paliatywnej i hospicyjnej (dalej: r.o.p.h.) ${ }^{36}$. Artykuł 15 ust. 2 pkt 11 ww. ustawy zalicza do świadczeń gwarantowanych opiekę paliatywną i hospicyjną. Natomiast $\S 3$ ust. 1. r.o.p.h. wprowadza do krajowego porządku prawnego następującą definicję: świadczenia opieki paliatywnej i hospicyjnej to wszechstronna, całościowa opieka i leczenie objawowe świadczeniobiorców chorujących na nieuleczalne, niepoddające się leczeniu przyczynowemu, postępujące, ograniczające życie choroby. Opieka ta jest

30 Por. K. de Walden-Gałuszko, dz. cyt., s. 11.

31 Por. tenże, U kresu. Opieka psychopaliatywna, czyli jak pomóc choremu, rodzinie i personelowi medycznemu środkami psychologicznymi, Gdańsk 1996, s. 18.

32 Por. A. Ciałkowska-Rysz, T. Dzierżanowski, Opieka paliatywna w onkologiiaktualne problemy i propozycje rozwiazań systemowych, w: Zachorowalność i umieralność na nowotwory a sytuacja demograficzna Polski, red. A. Potrykowska, Z. Strzelecki, J. Szymborski, J. Witkowski, Warszawa 2014, s. 166.

33 C. Centeno, T. Lynch, O. Donea, J. Rocafort, D. Clark, EAPC Atlas of Palliative Care in Europe 2013 - Full Edition, Milan: EACP Press; 2013, s. 334-237.

34 Por. A. Ciałkowska-Rysz, T. Dzierżanowski, dz. cyt., s. 166.

35 Dz.U. z 2017 r. poz. 1938 z późn. zm.

36 Dz.U. z 2013 r. poz. 1938 z późn. zm. 
ukierunkowana na poprawę jakości życia, ma na celu zapobieganie bólowi i innym objawom somatycznym oraz ich uśmierzanie, łagodzenie cierpień psychicznych, duchowych i socjalnych. Paragraf 4 stanowi z kolei, że powyższe świadczenia realizowane są w warunkach:

1. stacjonarnych $-\mathrm{w}$ hospicjum stacjonarnym lub w oddziale medycyny paliatywnej;

2. domowych - w hospicjum domowym dla dorosłych lub dla dzieci do ukończenia 18. roku życia;

3. ambulatoryjnych - w poradni medycyny paliatywnej;

4. perinatalnej opieki paliatywnej - w ośrodku diagnostyki prenatalnej, w ośrodku kardiologii prenatalnej, w zakładzie genetyki, w poradni medycyny paliatywnej, w hospicjum domowym dla dzieci lub w hospicjum stacjonarnym.

Zgodnie z $§ 5$ rozporządzenia świadczenia gwarantowane z zakresu opieki paliatywnej mogą obejmować:

1. świadczenia opieki zdrowotnej udzielane przez lekarzy;

2. Świadczenia opieki zdrowotnej udzielane przez pielęgniarki;

3. leczenie farmakologiczne;

4. leczenie bólu zgodnie z wytycznymi Światowej Organizacji Zdrowia (drabina analgetyczna);

5. leczenie innych objawów somatycznych;

6. opiekę psychologiczną nad świadczeniobiorcą i jego rodziną;

7. rehabilitację;

8. zapobieganie powikłaniom;

9. badania zlecone przez lekarza zatrudnionego w hospicjum stacjonarnym lub oddziale medycyny paliatywnej;

10. zaopatrzenie w wyroby medyczne konieczne do wykonania świadczenia gwarantowanego w hospicjum stacjonarnym lub w oddziale medycyny paliatywnej;

11. opiekę wyręczającą obejmującą przyjmowanie świadczeniobiorców do hospicjum stacjonarnego lub oddziału medycyny paliatywnej na okres nie dłuższy niż 10 dni.

Natomiast $\S 9$ rozporządzenia wskazuje, że w celu objęcia pacjenta opieką paliatywną konieczne jest skierowanie wystawione przez lekarza ubezpieczenia zdrowotnego oraz wskazanie medyczne (fakt występowania jednostki chorobowej, określonej szczegółowo przez to rozporządzenie) $)^{37}$.

37 Zob. J. Jarosz, Opieka paliatywna i leczenie przeciwbólowe w onkologii, w: Podstawy onkologii klinicznej, red. J. Meder, Warszawa 2011, s. 204-205. 
I tak, według danych NFZ na styczeń 2018 r. ${ }^{38}$, Dolnośląski Oddział Wojewódzki NFZ posiada zawartą umowę $\mathrm{w}$ zakresie opieki paliatywnej z 32 świadczeniodawcami, kujawsko-pomorski - 21, lubelski - 26, lubuski - 14, łódzki - 32, małopolski - 40, mazowiecki - 70, opolski - 11, podkarpacki - 46, podlaski - 15, pomorski-28, śląski - 51, świętokrzyski - 19, warmińsko-mazurski-24, wielkopolski-54, zachodniopomorski - 23 . W rzeczywistości jednak mamy do czynienia z poważnym problemem wynikającym, po pierwsze, z limitowaniem świadczeń. To właśnie limitowanie świadczeń powoduje kolejki osób, oczekujących na miejsca w hospicjach stacjonarnych, czy domowych (w niektórych województwach nawet 4 miesiące). Niestety wiele $\mathrm{z}$ tych osób umiera zanim zostanie poddana opiece paliatywnej w hospicjum. Sytuacja ta w kontekście prawa do godnego umierania jest niedopuszczalna ${ }^{39}$. Po drugie, według standardów wyznaczonych przez Europejskie Towarzystwo Opieki Paliatywnej, na 1 milion mieszkańców powinno przypadać co najmniej 100 łóżek opieki paliatywnej. Natomiast w Polsce, według danych z 2016 r., najbardziej dramatyczna sytuacja jest w województwie zachodniopomorskim, gdzie na $1 \mathrm{mln}$ mieszkańców jest tylko 26 łóżek, w łódzkim - 38, mazowieckim - 47, czy lubuskim - 54 (a trzeba mieć na względzie, że coraz większa liczba pacjentów będzie wymagała opieki paliatywnej). Ten stan rzeczy wynika ze zróżnicowania nakładów NFZ w przeliczeniu na 1 mieszkańca. W związku z powyższym koniecznym jest zniesienie limitu świadczeń z zakresu opieki paliatywnej, jak i podniesienie dostępności świadczeń z zakresu opieki paliatywnej w poszczególnych województwach poprzez podwyższenie nakładów ze strony NFZ ${ }^{40}$.

Dopiero od momentu zapewnienia choremu terminalnie tych podstawowych świadczeń z zakresu opieki paliatywnej można zacząć mówić o objęciu tą opieką także rodziny. Bo jaki sens ma sprawowanie opieki nad rodziną, jeżeli nie można o niej mówić w kontekście pacjenta? Idąc dalej, jeżeli umierający posiada prawo do opieki paliatywnej, to prawo to przysługuje na zasadzie emanacji (pośrednio) także rodzinie. Dopiero włączenie pacjenta w opiekę paliatywną pociąga za sobą możliwość wypełnienia przez świadczeniodawcę innych zadań z zakresu opieki na rzecz członków rodziny - opieka psychologiczna, duchowa. W tym aspekcie prawa chorego terminalnie nie rzadko stanowią podstawę istnienia praw rodziny pacjenta.

38 http://www.nfz.gov.pl/o-nfz/informator-o-zawartych-umowach/ [dostęp: 19.01.2018 r.].

39 Por. I. Lipowicz, Godność ludzka w świetle prawa administracyjnego, w: O madre prawo $i$ wrażliwe państwo, red. S. Trociuk, Warszawa 2013, s. 45-47.

40 Por. A. Ciałkowska-Rysz, Wywiad z drn. med. Aleksandra Ciatkowska-Rysz-Prezes Polskiego Towarzystwa Medycyny Paliatywnej, II Forum Medycyny Paliatywnej, Warszawa 2017, http://www.medycynapaliatywna.org [dostęp: 11.01.2018 r.]. 


\section{W świetle prawa do godnego umierania}

Podobnie jak w przypadku opieki paliatywnej, której podstawową treścią w zakresie medycznym jest leczenie objawowe - leczenie przyczynowe bowiem nie odnosi już swojego skutku, prawo do godnego umierania wybija się nam na pierwszy plan - przed prawem do ochrony zdrowia, i stanowi dla nas jasny punkt odniesienia w przestrzeni normatywnej. Jest ono rezultatem uznania godności za wartość i zasadę konstytucyjną i rodzi rzeczywiste obowiązki po stronie władzy publicznej, ale i także po stronie rodziny. Bo, czy na przykład obowiązek do pozostawienia takiej osoby w spokoju (right to be alone) nie spoczywa także na rodzinie? $\mathrm{Na}$ to pytanie trzeba odpowiedzieć twierdząco, a dodatkowo należy dodać, że administracja publiczna winna zapewnić, aby ten spokój nie został przez nikogo naruszony ${ }^{41}$.

Na gruncie normatywnym prawo do godnego umierania zostało uregulowane we wspominanej już ustawie o prawach pacjenta i Rzeczniku Praw Pacjenta. Rozdział 6 tej ustawy, zatytułowany Prawo do poszanowania intymności i godności pacjenta, stanowi m.in., że pacjent ma prawo do poszanowania intymności i godności, w szczególności w czasie udzielania mu świadczeń zdrowotnych. Prawo do poszanowania godności obejmuje także prawo do umierania w spokoju i godności.

$\mathrm{W}$ ten sposób prawo do godnego umierania staje się podstawą innych praw pacjenta. Do tych praw należy zaliczyć:

- $\quad$ prawo do wolności od uporczywej terapii ${ }^{42}$;

- prawo do łagodzenia bólu i innych cierpień;

- prawo do wyrażenia zgody lub sprzeciwu wobec proponowanej terapii;

- prawo do informacji o stanie zdrowia chorego ${ }^{43}$.

W obszarze prawa do wolności od uporczywej terapii ${ }^{44}$, prawa do łagodzenia bólu i innych cierpień, prawa do wyrażania zgody lub sprzeciwu wobec proponowanej terapii, rola rodziny, z prawnego punktu widzenia, może mieć doniosłe znaczenie. W szczególności wtedy, kiedy mamy do czynienia z pacjentami o ograniczonej zdolności do podejmowania decyzji. Bowiem zgodnie z art. 32 ust. 2 oraz 34 ust. 3

${ }^{41}$ Por. I. Lipowicz, dz. cyt. 45-46.

42 Por. M. Szeroczyńska, Odstapienie od uporczywej terapii de lege lata i de lege ferenda, „Medycyna Paliatywna” 2013, nr 2, str. 31-40.

43 Por. M. Śliwka, A. Gałęska-Śliwka, Godna śmierć a osoby niezdolne do decydowania, „Medycyna Paliatywna w Praktyce” 2012, tom 6, nr 1, s. 17.

44 Poprzez uporczywą terapię rozumiemy stosowanie środków i zabiegów medycznych nieproporcjonalnych w stosunku do zakładanego rezultatu, powodujące sztuczne wydłużenie procesu umierania, łączące się z nadmiernym cierpieniem pacjenta. 
ustawy z 5 grudnia o zawodach lekarza i lekarza dentysty (u.z.l. ${ }^{45}$, jeżeli pacjent jest małoletni lub niezdolny do świadomego wyrażenia zgody, wymagana jest zgoda jego przedstawiciela ustawowego, a gdy pacjent nie ma przedstawiciela ustawowego lub porozumienie się z nim jest niemożliwe - zezwolenie sądu opiekuńczego. Podobnie art. 17 ust. 2 u.p.p., który stanowi, iż przedstawiciel ustawowy pacjenta małoletniego, całkowicie ubezwłasnowolnionego lub niezdolnego do świadomego wyrażenia zgody, ma prawo do wyrażenia zgody na przeprowadzenie badania lub udzielenie innych świadczeń zdrowotnych. Z kolei na podstawie art. 98 § 1 kodeksu rodzinnego i opiekuńczego (dalej: k.r.o.) ${ }^{46}$ zgodę zastępczą za małoletniego wydają rodzice, którzy są przedstawicielami ustawowymi dziecka pozostającego pod ich władzą rodzicielską. Jeżeli dziecko pozostaje pod władzą rodzicielską obojga rodziców, każde z nich może działać samodzielnie jako przedstawiciel ustawowy dziecka. Jednakże o istotnych sprawach dziecka rodzice rozstrzygają wspólnie; w braku porozumienia między nimi rozstrzyga sąd opiekuńczy (art. $97 \S 2$ k.r.o.).

Wartym uwagi jest również fakt, że ustawodawca w art. 20 ust. 2 u.p.p. wyraźnie potwierdził, iż prawo do poszanowania godności obejmuje także prawo do umierania w spokoju i godności. W ten sposób wskazuje, że przysługujące pacjentowi prawa przysługują także w okresie umierania, czyli także wtedy, gdy lekarz, jako gwarant, utracił zdolność ochrony innego konstytucyjnego dobra, jakim jest życie człowieka. Wobec więc nieodwracalnego procesu umierania, któremu lekarz nie jest w stanie zapobiec, na plan pierwszy wychodzą inne prawa pacjenta, których lekarz nie tylko jest zobowiązany przestrzegać, ale także ciąży na nim obowiązek ich ochrony. Artykuł 20 ust. 2 u.p.p. posiadał jeszcze do niedawna ${ }^{47}$ drugie zdanie o treści: „Pacjent znajdujący się w stanie terminalnym ma prawo do świadczeń zdrowotnych zapewniających łagodzenie bólu i innych cierpień". Przepis ten stanowił wyraźne wskazanie priorytetu terapeutycznego dla lekarza wobec pacjenta terminalnie chorego. Owo wskazanie, mimo zmiany ustawy, mającej na celu słuszne rozszerzenie prawa do leczenia bólu na wszystkich pacjentów - art. 20a u.p.p., pozostaje aktualne. Niemniej jednak należy uznać za regres, że znalezienie podstaw tego wskazania nie wynika już z lektury obowiązującej u.p.p., ale wymaga szerszej analizy ustawy zmieniającej i jej uzasadnienia. Wracając jednak do kwestii łagodzenia bólu należy wskazać, że wspomniana wyżej zmiana celów terapeutycznych nie jest jedną z możliwości postępowania lekarskiego, która może podlegać jego swobodnej ocenie, lecz ma charakter obligatoryjny od chwili stwierdzenia braku możliwości przerwania procesu śmierci. Obowiązek ten dodatkowo potwierdza art.

45 Dz.U. z 2017 r. poz. 125 z późn. zm.

46 Dz.U. z 2017 r. poz. 682.

47 Zmiana z 11 maja 2017 r. - Dz.U. z 2017 r. poz. 836. 
36 ust. 6 u.z.l., który stanowi, iż lekarz podczas udzielania świadczeń zdrowotnych ma obowiązek poszanowania intymności i godności osobistej pacjenta. Dlatego też kluczową kwestią w tym aspekcie jest właściwe rozpoznanie przez lekarza momentu, w którym proces umierania stał się nieodwracalny, a wysiłki nastawione na jego przerwanie naruszają jedynie godność, stając się źródłem dodatkowych, sztucznie przedłużanych cierpień - terapia daremna. Działanie takie stanowi nie tylko błąd medyczny, lecz jest także pozbawionym legalności naruszeniem praw pacjenta umierającego i może rodzić określone skutki prawne. Przykładem może być tutaj art. 4 ust. 2 u.p.p., który stanowi, iż w razie zawinionego naruszenia prawa pacjenta do umierania w spokoju i godności sąd może, na żądanie małżonka, krewnych lub powinowatych do drugiego stopnia w linii prostej lub przedstawiciela ustawowego, zasądzić odpowiednią sumę pieniężną na wskazany przez nich cel społeczny na podstawie art. 448 Kodeksu cywilnego. W takiej sytuacji rodzina, posiadając możliwość wystąpienia do sądu z roszczeniem niejako w zastępstwie samego pacjenta, staje się częścią instytucji prawnej gwarantującej realizację praw chorego. W świetle powyższych przepisów oczywistą jest także możliwość rodziny domagania się od lekarza skutecznej terapii uśmierzającej ból ${ }^{48}$.

Odnosząc się właśnie do kwestii bólu należy mieć na względzie, że bardzo ważną kwestią jest monitorowanie jego poziomu tak, aby w sposób adekwatny i efektywny móc go uśmierzyć. W tym celu stosowana jest trzystopniowa drabina analgetyczna ${ }^{49}$. W sytuacjach skrajnych - kiedy nie da się opanować cierpienia chorego (np. narastająca duszność, napady paniki w okresie umierania), można zastosować tzw. sedację paliatywną. Polega ona na wprowadzeniu chorego w stan płytkiego lub głębokiego snu poprzez wprowadzenie określonych leków. Postępowanie to wymaga uzgodnienia z chorym i jego bliskimi. Stosowanie sedacji paliatywnej przynosi podwójny skutek: pożądany (ulga w cierpieniu nie do zniesienia) i niekorzystny (uśpienie chorego łączy się z częściowym lub pełnym pozbawieniem go świadomości, a więc możliwości składnia oświadczeń woli, oraz może niekiedy u chorego stanowić zagrożenie życia). Niemniej jednak, należy przyjąć jako naczelną zasadę obowiązek lekarza niesienia chorym terminalnie ulgi w cierpieniach, co zostało już wykazane wyżej. Dlatego też wydaje się wysoce wskazane, aby szczególny nacisk położyć nie tylko na monitorowanie poziomu bólu, ale także na ogólną jakość

48 Por. J. Siewiera, A. Kübler, Terapia daremna dla lekarzy i prawników, Wrocław 2015, s. 61-63.

49 Drabina analgetyczna została zdefiniowana przez Światową Organizację Zdrowia w 1986 r. i stanowi ona schemat stosowania leków przeciwbólowych. W schemacie tym wyróżnia się trzy stopnie intensywności leczenia, w zależności od poziomu odczuwania bólu przez chorego. 
życia chorego terminalnie. Może mieć to zasadniczy wpływ na sytuację prawną rodziny w zakresie egzekwowania od lekarza wypełnienia obowiązku niesienia ulgi umierającemu pacjentowi. Dlatego też, kolejnym postulatem jest wprowadzenie obligatoryjnego badania jakości życia chorych terminalnie. Można by się tu posłużyć np. Indeksem Spitzera ${ }^{50}$ lub, jak postuluje prof. I. Lipowicz, badaniem na podobieństwo 10 punktowej skali Apgar, określającej stan noworodka.

Z powyższą kwestią nieodzownie związana jest kwestia prawa do informacji o stanie zdrowia chorego. Zgodnie z art. 31 ust. 1 u.z.l. lekarz ma obowiązek udzielać pacjentowi lub jego ustawowemu przedstawicielowi przystępnej informacji o jego stanie zdrowia, rozpoznaniu, proponowanych oraz możliwych metodach diagnostycznych, leczniczych, dających się przewidzieć następstwach ich zastosowania albo zaniechania, wynikach leczenia oraz rokowaniu. Na podstawie art. 16 pkt 2 ustawy z dnia 15 lipca 2011 r. o zawodach pielęgniarki i położnej ${ }^{51}$ obowiązek informowania dotyczy również pracy pielęgniarek i położnych. Są one zobowiązane udzielić pacjentowi lub jego przedstawicielowi ustawowemu albo osobie wskazanej przez pacjenta informacji o stanie zdrowia pacjenta, w zakresie koniecznym do sprawowania opieki pielęgnacyjnej. Te obowiązki stanowią oczywisty korelat prawa pacjenta do uzyskania informacji o swoim stanie zdrowia, określonym $\mathrm{w}$ art. 9 ust. 1 u.p.p. Osobą uprawnioną do uzyskania informacji na temat stanu zdrowia i stosowanych procedur medycznych jest co do zasady sam pełnoletni pacjent. Niemniej jednak informację w powyższym zakresie należy również udzielić m.in. przedstawicielowi ustawowemu (rodzice, opiekunowie) oraz osobie, w stosunku do której pacjent lub jego przedstawiciel ustawowy wyraził zgodę na udzielenie informacji na temat stanu zdrowia pacjenta i stosowanych procedur medycznych (art. 31 ust. 2 u.z.l.). W tych powyższych przypadkach rodzina nie musi, ale może się stać podmiotem prawa do uzyskania informacji o stanie zdrowia chorego. Trzeba też podkreślić, że jest sytuacją niedopuszczalną przekazywanie informacji przez osoby wykonujące zawody medyczne np. członkom rodziny (dziennikarzom, etc.), jeżeli nie zostali oni do tego upoważnieni przez pacjenta. Natomiast w sytuacji, o której mowa w art. 31 ust. 6 u.z.l., kiedy pacjent nie ukończył 16 lat lub jest nieprzytomny bądź niezdolny do zrozumienia znaczenia informacji, lekarz udziela informacji osobie bliskiej w rozumieniu art. 3 ust. 1 pkt 2 u.p.p. $Z$ reguły będzie to właśnie rodzina. Wartym zauważenia jest też uprawnienie pacjenta, aby nie została mu udzielona informacja o jego stanie zdrowia (art. 9 ust. u.z.l., art. 31 ust. 3 u.p.p.). Co ważne jednak uprawnienie to nie przysługuje już przedstawicielowi

50 Por. A. Graczyk, Jakość życia chorych objętych opieka paliatywna, domowa i stacjonarna a satysfakcja z opieki w ocenie chorego i bliskich, Poznań 2012, s. 91-92.

$51 \quad$ Dz.U. z 2018 r. poz. 123. 
ustawowemu, w tym rodzinie. Autonomia informacyjna doznaje także wyjątku za sprawą tzw. przywileju terapeutycznego, z którego, na mocy art. 31 ust. 4 (,W sytuacjach wyjątkowych, jeżeli rokowanie jest niepomyślne dla pacjenta, lekarz może ograniczyć informację o stanie zdrowia i o rokowaniu, jeżeli według oceny lekarza przemawia za tym dobro pacjenta. W takich przypadkach lekarz informuje przedstawiciela ustawowego pacjenta lub osobę upoważnioną przez pacjenta. $\mathrm{Na}$ żądanie pacjenta lekarz ma jednak obowiązek udzielić mu żądanej informacji."), może skorzystać lekarz. Abstrahując już od słusznej wątpliwości ${ }^{52}$, czy przywilej ten jest do pogodzenia z godnością człowieka, na naszą uwagę zasługuję fakt, iż lekarz w takiej sytuacji ma obowiązek udzielenia pełnej informacji na temat stanu zdrowia pacjenta i rokowaniach jego rodzinie, kiedy ta posiada status przedstawiciela ustawowego lub osoby upoważnionej. Trzeba też dodać, że w kręgach opieki paliatywnej kształtuje się umiejętność tzw. przekazywania złych wiadomości (breaking bad news). Zasady etyczne zawodu lekarza w tym zakresie zmieniały się przez dziesięciolecia. Poprzednik współczesnego Kodeksu Etyki Lekarskiej Zbiór Zasad Etyczno-Deontologicznych Polskiego Lekarza z 1984 r. - stanowił, iż ze względu na ochronę psychiczną chorego nie jest wskazane podawanie do jego wiadomości niepomyślnego rokowania. Należy natomiast wtajemniczyć w nie wybraną osobę z otoczenia chorego (sic! $)^{53}$.

W przywołanym już wcześniej rozporządzeniu w sprawie świadczeń gwarantowanych z zakresu opieki paliatywnej i hospicyjnej odnajdujemy zapis, w którym do świadczeń gwarantowanych z zakresu medycyny paliatywnej zaliczamy także opiekę psychologiczną nad świadczeniobiorcą i jego rodziną ( 5 pkt 6 r.o.p.h.). Przepis ten stanowi autonomiczną podstawę prawa rodziny pacjenta chorego terminalnie do opieki paliatywnej w tym zakresie. W ten sposób państwo polskie uznaje swój obowiązek do wsparcia nie tylko pacjenta, ale i także jego rodziny.

Warto też zauważyć, że to samo rozporządzenie (r.o.p.h.) daje możliwość realizacji świadczeń z zakresu opieki paliatywnej w sposób wybiórczy. Na przykład lekarz (posiadający specjalizację w dziedzinie medycyny paliatywnej) realizuje świadczenie z zakresu medycyny paliatywnej, polegające tylko na konsultacji lekarskiej w domu świadczeniobiorcy. W ten prosty sposób wypaczeniu ulega nie tylko definicja opieki paliatywnej podana nam przez WHO, ale także prawo rodziny do objęcia jej opieką zawisa niejako w próżni.

Prawo i obowiązek rodziny do opieki nad chorym terminalnie może być przez nią samą w końcu nadużywane. Dzieje się tak kiedy na przykład w ramach opieki

52 Por. I. Lipowicz, dz. cyt., s. 46.

53 Por. A. Modlinska, L. Pawłowski, A. Wyszadko, T. Buss, M.Lichodziejewska-Niemierko, „Forum Medycyny Rodzinnej” 2013, tom 7, nr 1, s. 49-50. 
paliatywnej wykonywanej w warunkach domowych pacjent został poddany terapii przeciwbólowej, jednocześnie, z inicjatywy rodziny, prywatnie, ten sam pacjent jest leczony chemioterapią. W ten sposób dochodzi do swoistej koincydencji świadczeń, która negatywnie wpływa na obie terapie. Hospicja z tym problemem spotykają się dosyć często. Niemniej jednak wydaje się, że rozwiązać ten problem można tylko poprzez informowanie rodziny o niepożądanych skutkach takich działań. Ograniczanie prawa rodziny do opieki nad chorym terminalnie wydaje się mimo wszystko nie uzasadnione.

\section{Perinatalna opieka paliatywna}

Z początkiem 2017 r. wprowadzono do r.o.p.h. zmianę ${ }^{54}$ polegającą na dodaniu do świadczeń gwarantowanych z zakresu opieki paliatywnej świadczenie stanowiącą perinatalną opiekę paliatywną. Opieka ta, zgodnie z $\S 2$ pkt 3 r.o.p.h, powinna zapewnić: wsparcie rodzicom dziecka, w tym także będącego w fazie prenatalnej oraz komfort i ochronę przed uporczywą terapią wobec noworodków z ciężkim i nieodwracalnym upośledzeniem albo nieuleczalną chorobą zagrażającą życiu, które powstały w prenatalnym okresie rozwoju dziecka lub w czasie porodu ${ }^{55}$. Trzeba wspomnieć, że Polski model hospicjum perinatalnego został wprowadzony w 1999 r. jako rozwiązanie oryginalne i właśnie jako takie uzyskało ostatecznie miano najlepszego na świecie ${ }^{56}$. Jej wartość wynika również z tego, że może ona stanowić alternatywę wobec eugenicznej aborcji czy uporczywej terapii ${ }^{57}$.

54 Dz.U. z 2017 r. poz. 236.

55 Definicja ta koresponduje $\mathrm{z}$ tą ustanowioną wcześniej przez Polskie Towarzystwo Pediatryczne: ,perinatalna opieka paliatywna polega na zapewnieniu wszechstronnego wsparcia rodzicom płodów i noworodków z wadami letalnymi (...) oraz opieki noworodkom z tymi wadami, nastawionej na zapewnienie komfortu i ochronę przed uporczywą terapią. Obejmuje leczenie objawowe u dziecka oraz wsparcie psychologiczne, socjalne i duchowe, a także wsparcie w żałobie dla rodziców. Opieka nad dzieckiem może być prowadzona na oddziale neonatologii lub w domu przez rodziców i hospicjum, jeżeli dziecko przeżyje poród i zostanie wypisane ze szpitala.", Standardy postepowania i procedury medyczne z zakresu pediatrycznej domowej opieki paliatywnej w hospicjach domowych dla dzieci, Warszawa 2015 r., s. 5.

56 Por. Standardy postepowania i procedury medyczne w hospicjach domowych dla dzieci, red. T. Dangel, Warszawa 2015, s. 9-13.

57 Por. T. Dangel, Wady letalne u noworodków - opieka paliatywna jako alternatywa wobec engenicznej aborcji, eugenicznego dzieciobójstwa i uporczywej terapii, w: Dzieckostudium interdyscyplinarne, red. E. Sowińska, Lublin 2008, s. 443-460. 
Ten rodzaj opieki siłą rzeczy angażuje i dotyczy rodziców. Zatem dostęp rodziny do perinatalnej opieki paliatywnej wraz ze wskazaną wyżej zmianą uległ zdecydowanej poprawie. W zakresie uprawnień rodziny, w szczególności rodziców, trzeba za $\S 7$ 7a r.o.p.h. wymienić:

1. porady i konsultacje lekarskie w poradni medycyny paliatywnej, hospicjum domowym dla dzieci lub hospicjum stacjonarnym;

2. porady psychologa w poradni medycyny paliatywnej, w hospicjum domowym dla dzieci lub w hospicjum stacjonarnym;

3. koordynację opieki przez:

a. zapewnienie współpracy ze świadczeniodawcą udzielającym świadczeń z zakresu położnictwa i ginekologii lub neonatologii, w warunkach leczenia szpitalnego lub porady specjalistycznej,

b. zapewnienie współpracy $\mathrm{z}$ hospicjum domowym dla dzieci lub z hospicjum stacjonarnym, pozwalającej na zachowanie ciągłości opieki nad dzieckiem w przypadku zaistnienia możliwości wypisu z oddziału, na którym przebywa dziecko,

c. zapewnienie współpracy z ośrodkiem diagnostyki prenatalnej, ośrodkiem kardiologii prenatalnej lub zakładem genetyki,

d. poinformowanie rodziców dziecka o możliwości pożegnania się ze zmarłym dzieckiem oraz o sposobie pochówku,

e. przekazanie informacji dotyczących postępowania w przypadku zgonu dziecka,

f. zapewnienie ciągłości leczenia stosownie do stanu zdrowia, po zakończeniu realizacji świadczenia gwarantowanego w warunkach perinatalnej opieki paliatywnej, w tym w uzasadnionych przypadkach opiekę paliatywną po urodzeniu dziecka oraz wsparcie w żałobie po śmierci dziecka przez udział w grupie wsparcia w żałobie.

Dodatkowo, oprócz uprawnień rodziców, o których była mowa już wyżej, wynikających z u.p.p. i u.z.l., perinatalna opieka paliatywna pozwala nam zwrócić uwagę na szczególne aspekty, które nam się wyłaniają w przypadku, kiedy mamy do czynienia $z$ hospicjum dla dzieci. Należy do nich chociażby prawo sprzeciwu (art. 32 u.z.l.), z którego mogą skorzystać rodzice, w sytuacji, kiedy nie wyrażają zgody na terapię proponowaną przez lekarza hospicjum. W tej sytuacji następuje wypisanie dziecka $\mathrm{z}$ hospicjum oraz według „Standardów postępowania i procedur medycznych w hospicjach domowych dla dzieci" ${ }^{58}$, następuje powiadomienie sądu rodzinnego i wojewódzkiego konsultanta w dziedzinie pediatrii. Wypisanie dziecka

58 Standardy postępowania i procedury medyczne w hospicjach domowych dla dzieci, red. T. Dangel, Warszawa 2015, s. 20. 
z hospicjum może nastąpić także w wyniku decyzji lekarza hospicjum na podstawie art. 38 u.z.l. (odstąpienie od leczenia pacjenta). Brak akceptacji rodziców nie ma tutaj żadnego znaczenia. Na lekarzu ciąży jedynie obowiązek wcześniejszego uprzedzenia o swojej decyzji, wskazania możliwości alternatywnego świadczenia, uzasadnienia decyzji oraz odnotowania tego faktu w dokumentacji medycznej. Ostatecznie, zgodnie ze wskazanymi wyżej standardami ${ }^{59}$, lekarz może wypisać dziecko z hospicjum domowego, w sytuacji, gdy rodzice nie są w stanie wykonywać zaleceń lekarza hospicjum np. z powodu depresji, alkoholizmu, wyczerpania. Dziecko wtedy w trybie pilnym powinno zostać umieszczone w szpitalu, czy w hospicjum stacjonarnym.

Szczególnym i stosunkowo nowym uprawnieniem, które pojawia nam się przy okazji omawiania perinatalnej opieki paliatywnej, jest prawo rodziców do pochowania dziecka martwo urodzonego, bez względu na czas trwania ciąży - art. 11 ust. 5a ustawy z dnia 31 stycznia 1959 r. o cmentarzach i chowaniu zmarłych ${ }^{60}$. Uprawnienie to realizowane jest przede wszystkim poprzez sporządzenie karty zgonu przez lekarza, na wniosek rodziców (osoby uprawnionej do pochowania).

\section{Podsumowanie}

Rola rodziny w opiece paliatywnej jest nieodzowna. Sytuacja administracyjnoprawna rodziny pacjenta $\mathrm{w}$ stanie terminalnym pozostaje $\mathrm{w}$ funkcji sytuacji chorego terminalnie i jest z nią (z tą sytuacją) silnie sprzężona. Oznacza to, że im bardziej będzie poprawiać się sytuacja administracyjnoprawna pacjenta, tym lepsza będzie sytuacja administracyjnoprawna jego rodziny. Co oznacza lepsza? Punkt wyjścia stanowi dla nas prawo do godnego umierania, zakotwiczone w Konstytucji RP. To właśnie w tym prawie, prawie do umierania w spokoju, największym z możliwych i z należną mu ludzką godnością, ukonkretnia się godność człowieka $w$ fazie terminalnej ${ }^{61}$.

$\mathrm{Z}$ analizy dotychczasowych praw rodziny, której próby dokonano powyżej, wyłania nam się pozy tywny obraz uprawnień rodziny w zakresie opieki paliatywnej nad chorym. Oprócz aspektów, które wymagają pilnej interwencji (limitacja świadczeń, niedofinansowanie), należy zwrócić jeszcze uwagę na jeszcze jeden, podstawowy problem, który stanowi najgłębsze tło opieki paliatywnej w Polsce. Opieka paliatywna w Polsce narodziła się w ramach wielkiego ruchu hospicyjnego,

59 Tamże, s. 21.

60 Dz.U. z 2017 r. poz. 912.

61 Por. Papieska Rada ds. Duszpasterstwa Służby Zdrowia, Nowa Karta Pracowników Stużby Zdrowia, Katowice 2017, s. 130. 
zapoczątkowanego przez Cicely Saunders ${ }^{62}$, a więc w ramach inicjatywy „oddolnej”. I jako taka przez lata świetnie się zorganizowała, co zasługuje na bezdyskusyjne uznanie. Niemniej jednak sytuacja ta sprawiła, że administracja publiczna straciła niejako wzrok w tej materii, a na pewno inicjatywę. Mimo znacznych postępów legislacyjnych w zakresie prawa do godnego umierania i związanym z tym prawem, zapewnieniem finansowania świadczeń z zakresu opieki paliatywnej i hospicyjnej Polska nie osiągnęła jeszcze pożądanej jakości w sprawowaniu tej opieki. Postulaty prężnie działających środowisk hospicyjnych odnoszą się, zresztą słusznie, przede wszystkim do kwestii poziomu finansowania, a więc poruszają się w ramach aktualnego ustawodawstwa. Wydaje się jednak, że oprócz powyższego należy domagać się obecności państwa w opiece paliatywnej także w wymiarze ustrojowym. Państwo nie powinno być „ślepe” na potrzeby ludzi umierających fakt oczekiwania w kolejkach na przyjęcie do hospicjum jest tego dramatycznym przykładem. Owo „odzyskanie wzroku” powinno przynieść pożądany wymiar w administracji centralnej oraz samorządowej. Wizja ta wymaga oczywiście odrębnej analizy, ale tylko poprawa opieki paliatywnej w wymiarze instytucjonalnym, moim zdaniem, może przynieść oczekiwany efekt w podniesieniu jakości opieki paliatywnej i hospicyjnej. A to z kolei może stanowić istotny wkład w jak najlepszą realizację prawa pacjenta do godnej śmierci, które jest także prawem rodziny.

\section{Bibliografia}

Aszyk P., Stan terminalny, w: Encyklopedia bioetyki, red. A. Muszala, Radom 2005. Bąkowski T., Administracyjnoprawna sytuacja jednostki w świetle zasady pomocniczości, Warszawa 2007.

Boć J., Prawo administracyjne, Wrocław 2007.

Buczyński F., Lęki i potrzeby pacjenta i jego rodziny w terminalnym okresie choroby, w: VII Konferencja naukowa, Stużba człowiekowi u kresu życia, Jasna Góra 30 stycznia-1 lutego 2004 r., Częstochowa 2005.

Cebula H, Okres terminalny choroby, w: Dwudziestolecie opieki paliatywnej w Zakładzie Opiekuńczo-Leczniczym w Krakowie, red. J. Iwaszczyszyn, Kraków 2015.

Centeno C., Lynch T., Donea O., Rocafort J., Clark D., EAPC Atlas of Palliative Care in Europe 2013 - Full Edition, Milan: EACP Press; 2013.

62 Por. J. Iwaszczyszyn, J. Czekaj, Krótki rys historii opieki paliatywnej, w: Dwudziestolecie opieki paliatywnej w Zaktadzie Opiekuńczo-Leczniczym w Krakowie, red. J. Iwaszczyszyn, Kraków 2015, s. 19-22. 
Ciałkowska-Rysz A., Wywiad z dr n. med. Aleksandra Ciałkowska-Rysz Prezes Polskiego Towarzystwa Medycyny Paliatywnej, II Forum Medycyny Paliatywnej, Warszawa 2017, http://www.medycynapaliatywna.org [dostęp 11.01.2018 r.].

Ciałkowska-Rysz A., Dzierżanowski T., Opieka paliatywna w onkologii-aktualne problemy i propozycje rozwiazań systemowych, w: Zachorowalność $i$ umieralność na nowotwory a sytuacja demograficzna Polski, red. A. Potrykowska, Z. Strzelecki, J. Szymborski, J. Witkowski, Warszawa 2014.

Dangel T., Wady letalne u noworodków - opieka paliatywna jako alternatywa wobec eugenicznej aborcji, eugenicznego dzieciobójstwa i uporczywej terapii, w: Dziecko - studium interdyscyplinarne, red. E. Sowińska, Lublin 2008.

de Walden-Gałuszko K., Podstawy opieki paliatywnej, Warszawa 2004.

de Walden-Gałuszko K., U kresu, Opieka psychopaliatywna, czyli jak pomóc choremu, rodzinie i personelowi medycznemu środkami psychologicznymi, Gdańsk 1996.

Filipek J., Stosunek administracyjnoprawny, Kraków 1968.

Górecki M., Chory terminalnie i jego rodzina, „Ruch prawniczy, ekonomiczny i socjologiczny" 1999, rok 61, zeszyt 1.

Graczyk A., Jakość życia chorych objętych opieka paliatywna, domowa i stacjonarna a satysfakcja z opieki w ocenie chorego i bliskich, Poznań 2012.

Iwaszczyszyn J., Czekaj J., Krótki rys historii opieki paliatywnej, w: Dwudziestolecie opieki paliatywnej w Zaktadzie Opiekuńczo-Leczniczym $w$ Krakowie, red. J. Iwaszczyszyn, Kraków 2015.

Jan Paweł II, Familiaris consortio, 15, w: Acta Apostolicae Sedis 74, Watykan 1982. Jarosz J., Opieka paliatywna i leczenie przeciwbólowe w onkologii, w: Podstawy onkologii klinicznej, red. J. Meder, Warszawa 2011.

Koniuszewska E., Wptyw powiąań rodzinnych na czynności ogólnego postępowania administracyjnego, w: Rodzina w naukach prawnych. Zbiór studiów, red. M. Tkaczuk, R. Jaworska-Stankiewicz, Szczecin 2012.

Kowalczyk M., Opieka paliatywna jako jedna z form opieki nad pacjentem terminalnie chorym, w: „Państwo i Społeczeństwo”, rok XII, nr 2, red. F. Gołkowski, S. Kwiatkowski, Kraków 2012.

Lipowicz I., Godność ludzka w świetle prawa administracyjnego, w: O mąre prawo i wrażliwe państwo, red. S. Trociuk, Warszawa 2013.

Longchamps F., O pojęciu stosunku prawnego w prawie administracyjnym, „Acta Universitatis Wratislaviensis" 1964, nr 19, Prawo XII.

Modlińska A., Pawłowski L., Wyszadko A., Buss T., Lichodziejewska-Niemierko M., „Forum Medycyny Rodzinnej” 2013, tom 7, nr 1. 
Nitecki S., Stosunek administracyjnoprawny a samorzad terytorialny, w: Instytucje wspótczesnego prawa administracyjnego. Księa jubileuszowa Prof. zw. dra hab. Józefa Filipka, Kraków 2001.

Papieska Rada ds. Duszpasterstwa Służby Zdrowia, Nowa Karta Pracowników Stużby Zdrowia, Katowice 2017.

Raszeja S., Refleksje na temat tanatologii - klasycznego dziatu medycyny sadowej, w: „Annales Academiae Medicae Gedanensis” 2005, t. 35.

Rębiałkowska-Stankiewicz M., Diagnoza potrzeb rodzin pacjentów w stanie wegetatywnym, „Przegląd Pedagogiczny” 2015, nr 1.

Siewiera J., Kübler A., Terapia daremna dla lekarzy i prawników, Wrocław 2015.

Skórka A., Pojęcie „Rodziny” w ustawie o pomocy społecznej $i$ w postępowaniu o uzyskanie świadczeń z zakresu pomocy społecznej. Hybryda językowa czy celowy zamyst ustawodawcy, w: Ochrona matżeństwa i rodziny w Polsce. Zagadnienia prawne, red. J. Krzynówka, J. Krzywkowska, Olsztyn 2015.

Śliwka M., Gałęska-Śliwka A., Godna śmierć a osoby niezdolne do decydowania, „Medycyna Paliatywna w Praktyce” 2012, tom 6, nr 1.

Standardy postępowania i procedury medyczne whospicjach domowych dla dzieci, red. T. Dangel, Warszawa 2015.

Szeroczyńska M., Odstapienie od uporczywej terapii de lege lata i de lege ferenda, „Medycyna Paliatywna” 2013, nr 2.

Tyszka Z., Socjologia rodziny w Polsce, „Ruch Prawniczy, Ekonomiczny i Socjologiczny" 1990, rok LII, zeszyt 3-4.

Ziółkowska A., Gronkiewicz A., Rodzina w prawie administracyjnym - prolegomena, w: Rodzina $w$ prawie administracyjnym, red. A. Ziółkowska, A. Gronkiewicz.

Zubik M., Podmioty konstytucyjnych wolności, praw i obowiazków, „Przegląd Legislacyjny" 2007, nr 2(60).

\section{Mateusz Kruczkowski: Legal and administrative situation of terminal patient's family}

\section{Summary}

Patient's terminal state affects their family very specifically. The reality faced by the family includes anxiety and fear of solitude, helplessness, death, dying, worries about access to necessary medical equipment or about its failure, about pain and suffering of the dying person, deterioration of material conditions, social isolation, fear of the very sight and touch of the dead relative's body. The complexity of the 
problem involves emotions of every family member and the reactions of other members of the family concerning the death of the patient.

Palliative care is an approach that improves the quality of life of patients (adults and children) and their families who are facing problems associated with life-threatening illness. It prevents and relieves suffering through the early identification, correct assessment and treatment of pain and other problems, whether physical, psychosocial or spiritual. Thus palliative care is an adequate reaction to the state of the terminally ill patient and their family.

Both administrative and legal situation of the patient's family is strongly connected to the situation of the terminal patient. It means that improvement of patient's legal and administrative situation accordingly improves the legal and administrative situation of their family. What does improvement mean? The starting point here is the right to die with dignity, the right which is anchored in the Constitution of The Republic of Poland. It is in this aforementioned principle of law, which is the right to die as peacefully as it is possible and with dignity that is due to a human being, where the dignity of man in the terminal state is enclosed.

Keywords: palliative care, family, legal and administrative situation, right to die with dignity, terminal patient. 